\title{
PENGARUH JENIS BIOAKTIVATOR TERHADAP LAJU DEKOMPOSISI SERESAH DAUN JATI Tectona grandis L.f., DI WILAYAH KAMPUS UNHAS TAMALANREA
}

\section{EFFECT OF BIOACTIVATORS TYPES ON THE RATE OF TEAK Tectona grandis L. f., LEAF 'SERESAH' DECOMPOSITION , IN THE CAMPUS UNHAS TAMALANREA}

\author{
Andriany, Fahruddin, As'adi Abdullah \\ Departemen Biologi, FMIPA, Universitas Hasanuddin, Makassar \\ andriany.elfminos@gmail.com
}

\begin{abstract}
Abstrak
Sampah dari seresah daun di kampus telah menjadi masalah setiap hari, alternatif pengolahannya adalah menjadikan daun sebagai bahan pengomposan. Penelitian ini bertujuan mengetahui pengaruh jenis bioaktivator terhadap laju dekomposisi seresah daun jati Tectona grandis L.f., dan beberapa perubahan parameter terkait selama proses dekomposisi meliputi warna kompos, suhu, kadar air kompos, $\mathrm{pH}$, laju dekomposisi, dan rasio $\mathrm{C} / \mathrm{N}$. Adapun perlakuan sebagai berikut: PA daun Jati Tectona grandis L.f., (1 kg) ditambah 20\% kotoran sapi, PB daun Jati Tectona grandis L.f., (1 kg) ditambah $20 \%$ kotoran ayam, PC daun Jati Tectona grandis L.f., (1 kg) ditambah 20\% EM4 dan P0 daun Jati Tectona grandis L.f., $(1 \mathrm{~kg})$ tanpa bioaktivator sebagai kontrol. Pengamatan dilakukan selama 30 hari. Hasil penelitian menunjukkan jenis bioaktivator dapat mempengaruhi proses dekomposisi seresah daun Jati Tectona grandis L.f., dimana pada perlakuan PC menunjukkan laju dekomposisi tertinggi yaitu 0,65, dibandingkan dengan perlakuan PA yang hanya 0,62 dan PB serta kontrol hanya 0,50. Sedangkan parameter lain seperti suhu semua perlakuan berpruktuasi, kandungan air cenderung naik pada semua perlakuan, $\mathrm{pH}$ mendekati netral pada semua perlakuan, dan rasio $\mathrm{C} / \mathrm{N}$ memenuhi $\mathrm{SNI}$ pada perlakuan PA, PB, dan PC yaitu 10-20.
\end{abstract}

Kata kunci: bioaktivator; kompos; dekomposisi; Tectona grandis

\begin{abstract}
Abtract
Garbage from leaf litter on campus has been a problem every day, alternate processing is to make the leaves as composting material. This study aims to determine the effect of the type of bio-activator to the rate of leaf litter decomposition of teak Tectona grandis L.f., and some related parameters change during the decomposition process of compost include color, temperature, the moisture content of compost, $\mathrm{pH}$, the rate of decomposition, and $\mathrm{C} / \mathrm{N}$ ratio. As for treatment as follows: PA leaf Teak Tectona grandis L.f., $(1 \mathrm{~kg}$ ) plus $20 \%$ of cow dung, PB leaves Teak Tectona grandis L.f., $(1 \mathrm{~kg})$ plus $20 \%$ of chicken manure, PC leaves Teak Tectona grandis Lf $(1 \mathrm{~kg})$ plus $20 \%$ EM4 and P0 is Teakleaves Tectona grandis L.f., $(1 \mathrm{~kg})$ without a bio-activator as a control. Observations made during the 30 days. The results showed the type of bioactivator can affect the process of leaf litter decomposition of Teak Tectona grandis L.f., where the PC treatment showed the highest decomposition rate of 0,65 , compared to treatment with PA were only 0,62 and 0,50 PB and control only. Meanwhile, other parameters such as temperature fluctuates all treatments, the water content tends to increase in all treatments, $\mathrm{pH}$ close to neutral on all treatments, and the $\mathrm{C} / \mathrm{N}$ ratio to treatment with the SNI PA, PB, and PC are 10-20.
\end{abstract}

Keywords: bioactivator; compost; decomposition; Tectona grandis. 


\section{Pendahuluan}

Penghijauan di lingkungan Universitas Hasanuddin selain membawa dampak positif, juga terdapat efek samping dari kegiatan tersebut, berupa serasah daun yang menumpuk. Salah satu pohon penghasil seresah daun yang banyak dijumpai di wilayah Universitas Hasanuddin berasal dari daun Jati. Seresah daun tersebut dapat terurai secara alami, namun membutuhkan waktu yang lama. Waktu dekomposisi alami dari serasah daun untuk menjadi kompos yang siap dimanfaatkan oleh tumbuhan ataupun organisme lain di sekitarnya, umumnya membutuhkan waktu sekitar 4 bulan. Waktu dekomposisi daun yang lebih lambat dari pada waktu pengguguran daun, menyebabkan penumpukan limbah serasah karena tidak dapat segera terdekomposisi. Menurut Yulipriyanto (2009), salah satu upaya untuk membantu mengatasi permasalahan tersebut adalah melakukan upaya daur ulang seresah dengan penekanan pada proses pengomposan yaitu suatu proses mengubah atau memanfaatkan seresah daun sebagai bahan baku untuk memproduksi kompos. Pengomposan merupakan sistem pengelolaan sampah organik yang hingga kini makin digemari karena selain ramah lingkungan juga akan menghasilkan kompos sebagai pupuk organik yang sehat. Meskipun demikian, pemasyarakatan pengomposan sebagai pengolah sampah organik kepada masyarakat masih menemui banyak kendala, khususnya untuk sampah yang homogen seperti jenis daun. Oleh karena itu, pengomposan dengan penambahan berbagai aktivator yang paling efektif digunakan untuk memercepat laju dekomposisi sangat mungkin apalagi untuk sampah daun.

Serasah mengalami dekomposisi yang melibatkan peran mikroorganisme seperti bakteri dan fungi. Dekomposisi akan berjalan lebih cepat jika terdapat penambahan mikroorganisme tersebut. Bahan yang umum ditambahkan untuk mempercepat proses dekomposisi adalah bioaktivator. Oleh karena itu, dengan penambahan bioaktivator pada serasah daun tersebut,diharapkan proses dekomposisi akan lebih cepat (Hanum dan Kuswytasari, 2014). Bioaktivator adalah agen pengaktivasi yang berupa mahluk hidup (jasad renik) dan berperan mengawali proses perubahan baik aspek fisika maupun kimia suatu bahan organik menjadi produk yang berbeda sifatnya. Proses perubahan fisika-kimia bahan tersebut hingga menjadi molekul-molekul kecil bahkan menjadi komponen-komponen dan unsur-unsurnya yang dikenal dengan dekomposisi. Proses dekomposisi bahan organik tersebut dilakukan oleh jasad renik termasuk bakteri, aktinomiset, khamir dan kapang yang berperan sebagai agen bioaktivator (Sukanto, 2013).

Agen bioaktivator terdiri dari berbagai macam yang tersedia di pasaran antara lain OrgaDec, Stardec, EM-4, Fix-Up Plus, dan Harmony yang berfungsi untuk mempercepat proses pengomposan, meningkatkan kandungan bahan organik tanah, memperbaiki struktur tanah, dan ketersediaan hara dalam tanah dapat dilakukan menggunakan bioaktivator. Selain itu untuk mempercepat pengomposan tersebut juga dapat melibatkan organisme lain seperti cacing tanah yang bekerja sama dengan mikroba dalam proses penguraian (Sucipto, 2012). Berdasarkan latar belakang di atas, maka dilakukan suatu penelitian tentang pengaruh jenis bioaktivator terhadap laju dekomposisi seresah daun jati Tectona grandis L.f., di wilayah kampus Unhas.

\section{Metode Penelitian}

Alat-alat yang digunakan dalam penelitian ini yaitu cawan, timbangan, neraca Ohaus, sendok tanduk, pipet volume, oven, sekop, ember plastik, wadah plastik, thermometer, $\mathrm{pH}$ meter, mesin pencacah, gunting, dan timbangan. 
Bahan-bahan yang digunakan dalam penelitian ini adalah seresah daun Jati Tectona grandisL.f., yang di peroleh dari sekitar Fakultas Teknik Unhas, dan bioaktivator yaitu EM4 (Effective Microorganism-4)yang diperoleh dari Toko Tani Veteran, kotoran sapi dan kotoran ayam yang diperoleh dari Fakultas Peternakan Unhas, dan polybag.

\section{Prosedur Kerja}

\section{Pengumpulan seresah daun}

Pengumpulan seresah daun kering yakni daun Jati Tectona grandisL.f., diambil di sekitar Fakultas Teknik Unhas. Seresah tersebut dimasukkan dalam wadah plastik kemudian dilakukan pemilahan dilokasi pengomposan. Selanjutnya seresah daun dicacah untuk memperluas permukaan sampah sehingga mudah dan cepat terdekomposisi. Seresah daun yang sudah dicacah, lalu ditimbang. Kotoran sapi dan kotoran ayam diambil dari lokasi peternakan dan dimasukkan ke dalam wadah plastik. Kotoran sapi dan kotoran ayam yang digunakan adalah kotoran yang sudah dikeringkan.

\section{Pengomposan}

Seresah daun Jati yang telah dicacah sebanyak $1 \mathrm{~kg}$ kemudian dicampur dengan bioaktivator sebanyak $20 \%$. Kemudian dimasukkan ke dalam polybag dan dilakukan pembalikan untuk aerasi dan membuang panas berlebihan. Proses pengomposan dilakukan selama 30 hari, selama proses dilakukan pengukuran warna kompos, suhu dan $\mathrm{pH}$, pengukuran kadar air kompos setiap 5 hari dan laju dekomposisi dilakukan setiap 10 hari, sedangkan rasio $\mathrm{C} / \mathrm{N}$ dilakukan pada awal dan akhir pengomposan. Untuk menjaga kelembaban, ditambahkan air ke dalam timbunan material organik, karena diusahakan jangan sampai kering. Adapun perlakuan sebagai berikut:

PA : Daun Jati Tectona grandis L.f., ditambah 20\% kotoran sapi.

PB : Daun Jati Tectona grandis L.f., ditambah $20 \%$ kotoran ayam.

PC : Daun Jati Tectona grandis L.f., ditambah 20\% EM4.

PO : Daun Jati Tectona grandis L.f., tanpa penambahan bioaktivator.

\section{Hasil dan Pembahasan}

Seresah daun di lingkungan kampus Unhas telah menjadi masalah yang serius, seresah ini bersumber dari berbagai jenis pohon setiap harinya terutama seresah daun yang berasal dari pohon Jati Tectona grandis L.f., hal ini dapat ditanggulangi secara efektif dan ramah lingkungan melalui proses pengomposan. Oleh karena itu dilakukan kajian proses dekomposisi seresah dan Jati Tectona grandis L.f., dengan menggunakan tiga jenis bioaktivator, adapun perlakuannya adalah sbb: PA: kotoran sapi, PB: kotoran ayam, PC: EM4, dan P0: tanpa penambahan bioaktivator. Selama proses pengomposan dilakukan pengamatan aspek fisika dan kimia seperti warna kompos, suhu, kadar air, $\mathrm{pH}$, laju dekomposisi, dan kandungan rasio $\mathrm{C} / \mathrm{N}$.

\section{Warna Kompos}

Hasil pengamatan warna kompos untuk semua perlakuan menunjukkan perubahan dari warna kuning kecoklatan menjadi coklat kehitaman. Perubahan warna dapat dilihat dalam Gambar 1 berikut. 


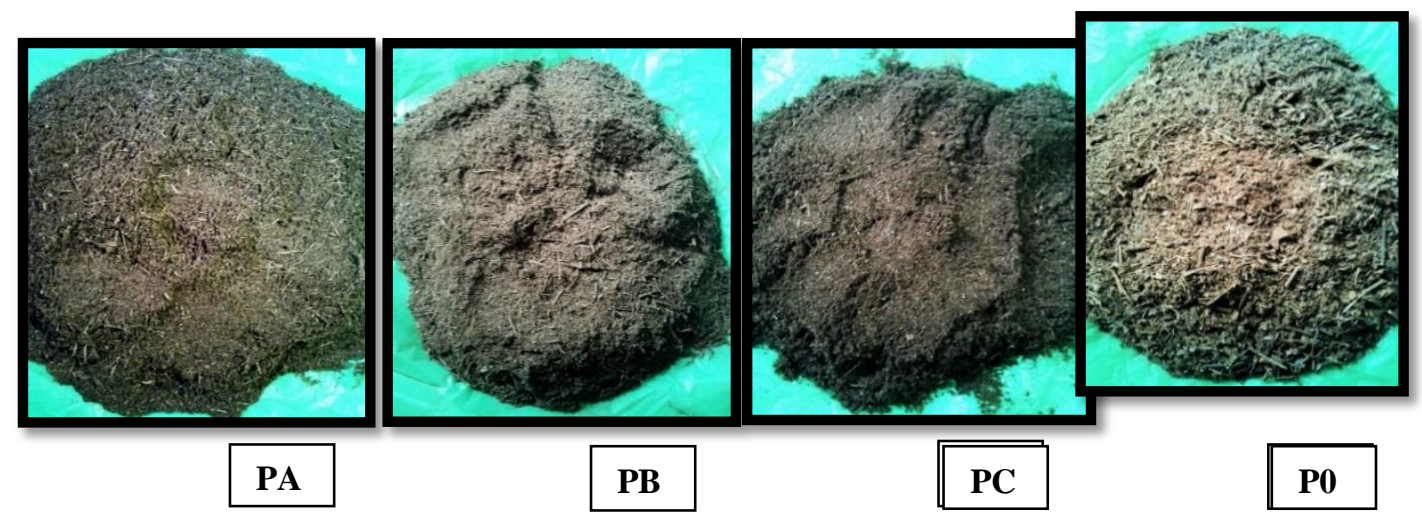

Gambar 1.. Hasil akhir warna kompos selama 30 hari daun Jati Tectona grandis L.f.,

Pada awal pengomposan, semua perlakuan memiliki warna yang sama dengan bahan mentahnya yaitu kuning kecoklatan. Pada akhir pengomposan, perlakuan PA, PB dan PC mengalami perubahan warna yaitu berwarna coklat kehitaman. PA, PB dan PC menunjukkan ciri fisik kompos yang baik, dimana warnanya coklat kehitaman, agak lembap, dan bahan mentahnya sudah tidak tampak lagi. Sedangkan untuk warna kontrol berwarna coklat dan bahannya belum terlalu lapuk, seperti yang terlihat pada Gambar 4. Pada proses pengomposan akan terjadi penguraian bahan organik oleh aktivitas mikroba yang mengambil air, oksigen, dan nutrisi bahan organik yang kemudian akan mengalami penguraian dan membebaskan $\mathrm{CO}_{2}$ dan $\mathrm{O}_{2}$. Hal ini terjadi karena pangaruh bahan bioaktivator yaitu kotoran sapi, kotoran ayam, dan EM4 yang mempercepat proses pematangan kompos (Gaur, 1986).

Menurut Yuniwati (2012) kompos yang baik adalah kompos yang sudah mengalami pelapukan dengan ciri-ciri warna yang berbeda dengan warna bahan pembentuknya, tidak berbau, kadar air rendah, dan mempunyai suhu yang sama dengan suhu ruang. Perubahan sifat fisik kompos yaitu warna kompos dari kuning kecoklatan menjadi coklat kehitaman terjadi akibat adanya proses penguraian yang dilakukan oleh mikroba.

\section{Suhu Kompos}

Pada awal dekomposisi hari ke-0 semua perlakuan tidak memperlihatkan perbedaan yang nyata. Suhu daun setelah pencampuran berkisar rata-rata suhu yaitu $28-29^{\circ} \mathrm{C}$. Rata-rata suhu kompos dapat dilihat pada Gambar 2. Pada perlakuan PA, PB, P0 memperlihatkan rata-rata suhu awal pengomposan yang sama yaitu $28^{\circ} \mathrm{C}$ dan pada perlakuan PC memperlihatkan rata-rata suhu tertinggi yaitu $29^{\circ} \mathrm{C}$. Pada hari ke-5 terjadi peningkatan suhu, semua perlakuan tidak memperlihatkan perbedaan yang nyata. Rata-rata suhu tertinggi adalah pada perlakuan $\mathrm{PC}$ yaitu $30,75^{\circ} \mathrm{C}$ dan nilai ratarata suhu terendah pada perlakuan PB dan P0 yaitu $28^{\circ} \mathrm{C}$.Pada hari ke-10 terjadi peningkatan suhu pada perlakuan PA, PC, dan P0 sedangkan pada perlakuan PB suhu tetap yaitu $28^{\circ} \mathrm{C}$. 


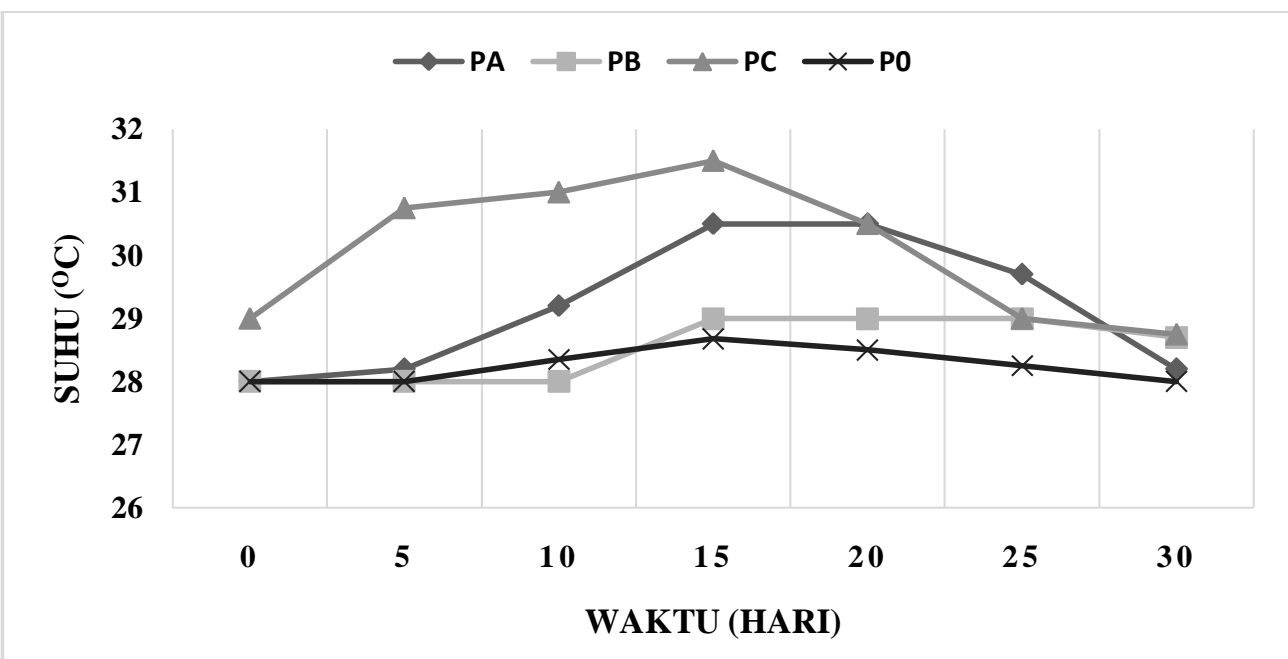

Gambar 2. Perubahan suhu dekomposisi seresah daun Jati Tectona grandis L.f.,

Pada hari ke-15 terjadi peningkatan suhu maksimum pada maing-masing perlakuan. Pada perlakuan PC memperlihatkan rata - rata suhu tertinggi yaitu $31,50 \mathrm{C}$, perlakuan PA memperlihatkan rata-rata suhu yaitu $30,5^{\circ} \mathrm{C}$ perlakuan $\mathrm{PO}$ memperlihatkan rata - rata suhu $28,68^{\circ} \mathrm{C}$, dan pada $\mathrm{PB}$ memperlihatkan nilai rata-rata suhu terendah yaitu $29^{\circ} \mathrm{C}$. Pada hari ke-20 tidak terjadi peningkatan suhu pada masing-masing perlakuan. Suhu relatif konstan, rata-rata suhu tertinggi adalah pada perlakuan PA dan PC yaitu $30,5^{\circ} \mathrm{C}$ dan nilai rata-rata suhu terendah pada perlakuan PB yaitu $29^{\circ} \mathrm{C}$.Pada hari ke-25 penurunan suhu mulai terjadi pada masing-masing perlakuan. Rata-rata suhu tertinggi adalah pada perlakuan PA yaitu $29,7^{\circ} \mathrm{C}$ dan ratarata suhu terendah pada perlakuan $P 0$ yaitu $28,25^{\circ} \mathrm{C}$. Pada hari ke- 30 penurunan suhu mulai mendekati suhu awal pengomposan pada masing-masing perlakuan. Rata-rata suhu tertinggi adalah pada perlakuan PC yaitu $28,75^{\circ} \mathrm{C}$ dan rata-rata suhu terendah pada perlakuan $\mathrm{P0}$ yaitu $28^{\circ} \mathrm{C}$.

Suhu pengomposan yang dicapai dalam penelitian ini sekitar $28-31,5^{\circ} \mathrm{C}$, dan ini berlangsung optimal pada hari ke-15. Hal ini menunjukkan bahwa mikroba yang aktif adalah mikroba mesofilik, yaitu mikroba yang dapat hidup pada suhu antara $20-35^{\circ} \mathrm{C}$. Aktifitas mikroba mesofilik dalam proses penguraian akan menghasilkan panas dengan mengeluarkan $\mathrm{CO}_{2}$ dan mengambil $\mathrm{O}_{2}$ dalam tumpukan kompos sampai mencapai suhu maksimum (Isroi dan Yuliarti, 2009). Bahan kompos yang melewati suhu puncak, tumpukan mencapai stabilitas dimana bahan yang mudah diubah telah diuraikan, dan kebanyakan kebutuhan oksigen yang tinggi telah terpenuhi. Hasil penelitian menunjukkan bahwa dari keempat perlakuan, suhu mulai meningkat pada hari ke-5 yang menandakan awal dimulainya proses dekomposisi. Peningkatan suhu maksimum selama proses dekomposisi mencapai $31,5^{\circ} \mathrm{C}$. Berdasarkan grafik yang disajikan pada Gambar 5, terlihat bahwa pada perlakuan yang menunjukkan peningkatan suhu tertinggi adalah perlakuan PC yang ditandai dengan kenaikan suhu pada hari ke-5 hingga hari ke-15, setelah itu suhu menjadi turun pada hari ke-20 sampai pada akhir pengomposan yaitu pada suhu $28,75^{\circ} \mathrm{C}$. Hal ini sesuai yang dikemukakan oleh Widawati (2005) bahwa selama proses pengomposan, suhu yang awalnya normal dalam tumpukan kompos secara bertahap mengalami peningkatan dan akan mencapai suhu maksimum, kemudian akan menurun terus-menerus sampai menjadi stabil pada saat kompos matang.

Menurut Syahwan (2010) meningkatnya temperatur dihasilkandari metabolisme mikroba (hasil respirasi) danterinsulasi oleh material yang dikomposkan. Mikroba tidak 
benar-benar efisien dalam mengkonversikan dan menggunakan energi. Baon (1996) menyatakan bahwa penumpukan bahan organik pada kondisi suhu dan lingkungan yang sesuai bagi mikroba akan mempercepat proses penguraian, dimana mikroba akan menggunakan nutrisi dari bahan organik sebagai sumber energi bagi aktifitasnya.

Mikroba juga akan berkembang biak dengan cepat sambil membebaskan sejumlah energi berupa panas pada tumpukan kompos, dan panas tersebut akan meningkatkan suhu. Pada saat proses pengomposan mencapai suhu maksimum persediaan oksigen akan terbatas, sehingga mengakibatkan penurunan suhu (Widawati, 2005).

\section{Kadar Air Kompos}

Awal pengomposan semua perlakuan tidak mempelihatkan perbedaan yang nyata. Nilai rata-rata persentase kadar air tertinggi adalah pada perlakuan PC yaitu $42,86 \%$ dan nilai persentase terendah adalah perlakuan P0 yaitu $28,13 \%$. Hari ke-10, persentase kadar air mengalami peningkatan. Nilai rata-rata persentase kadar air tetinggi adalah pada perlakuan PC yaitu $47,75 \%$ dan rata-rata persentase kadar air terendah adalah perlakuan P0 yaitu 38,6\%. Hari ke-20 persentase kadar air meningkat. Nilai persentase kadar air tertinggi adalah pada perlakuan PC yaitu 58,22\% dan terendah pada perlakuan P0 yaitu 46,40\%. Hari ke-30 terjadi kenaikan nilai kadar air pada semua perlakuan. Nilai persentase kadar air tertinggi adalah pada perlakuan PC yaitu $60,52 \%$ dan terendah pada perlakuan P0 yaitu $48,16 \%$. Persentase kadar air kompos dapat dilihat pada Gambar 3.

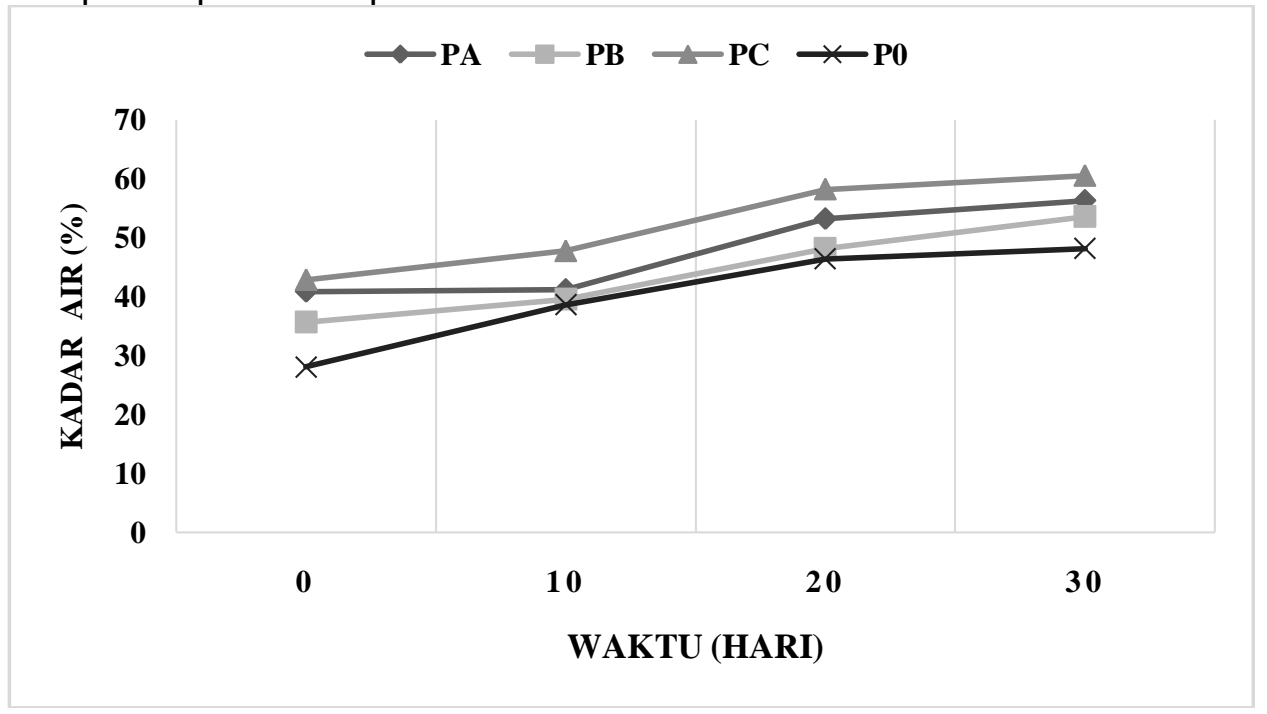

Gambar 3. Perubahan kadar air kompos seresah daun Jati Tectona grandis L.f.,

Setiap perlakuan mengalami kenaikan sampai hari ke-30. Menurut Dalzell, et al., (1987), pada kadar air dibawah 30\% menyebabkan reaksi biologis dalam tumpukan kompos menjadi lambat. Pada kadar air yang terlalu tinggi, ruang antara partikel dari bahan penuh air, sehingga mencegah gerakan udara dalam tumpukan. Kadar air optimum dari bahan kompos adalah $50-60 \%$.

Air yang dihasilkan oleh mikroorganisme pada saat proses pengomposan akan hilang karena eveporasi ke dalam aliran udara. Dalam pembuatannya, bahan kompos sering lebih kering pada saat kondisi tropis dari pada iklim sedang. Bahkan juga akan mengering lebih cepat pada saat pembuatan kompos, biasanya dengan melakukan membasahi kompos pada awalnya, dan jika diperlukan dalam proses pengomposan (Allo, 2014). 
Menurut Rochaeni, et al., (2003) dan Shiddieqy (2005), jika tumpukan terlalu lembap, maka dekomposisi akan terhambat, hal ini disebabkan kadar air akan menutupi rongga udara di dalam tumpukan, sehingga akan membatasi kadar oksigen dalam tumpukan. Kekurangan oksigen akan mengakibatkan mikroorganisme aerobik mati dan akan tergantikan oleh mikroorganisme anaerobik. Menurut Isroi (2008) kondisi anaerob tidak diinginkan selama proses pengomposan karena akan dihasilkan bau yang tidak sedap karena terbentuknya senyawa-senyawa seperti: asam-asam organik (asam asetat, asam butirat, dan asam valerat), amonia dan $\mathrm{H}_{2} \mathrm{~S}$.

\section{Derajat Keasaman (pH) Kompos}

Hasil penelitian menunjukkan pada awal pengomposan nilai $\mathrm{pH}$ lama kelamaan akan berubah mendekati $\mathrm{pH}$ netral sesuai dengan $\mathrm{pH}$ tanah. Nilai $\mathrm{pH}$ pada hari ke-0 pada rata-rata nilai $\mathrm{pH}$ pada perlakuan $\mathrm{PA}$ dan $\mathrm{PO}$ memperlihatkan $\mathrm{pH}$ yaitu 6,0 , pada perlakuan $\mathrm{PB}$ rata $\mathrm{pH} 6,2$ dan pada perlakuan $\mathrm{P0}$ rata-rata $\mathrm{pH}$ yaitu 6,3 . Pada hari ke-5 proses dekomposisi dau Jati Tectona grandis L.f., mengalami peningkatan $\mathrm{pH}$, untuk perlakuan PA rata-rata nilai $\mathrm{pH}$ yaitu 6,2 , $\mathrm{PB}$ yaitu 6,3 , pada perlakuan $\mathrm{PC}$ rata-rata nilai $\mathrm{pH}$ yaitu 6,4 sedangkan pada perlakuan $\mathrm{PO}$ yaitu 6,1 .

Proses dekomposisi daun Jati Tectona grandis L.f., pada hari ke-10 mengalami peningkatan $\mathrm{pH}$ untuk semua perlakuan. Pada perlakuan PA dan PB memperlihatkan nilai $\mathrm{pH}$ yaitu 6,4 pada perlakuan PC yaitu 6,7 dan pada perlakuan P0 yaitu 6,2. Hari ke-15 pada semua perlakuan memperlihatkan peningkatan $\mathrm{pH}$ yaitu pada perlakuan PA memperlihatkan rata-rata nilai $\mathrm{pH}$ sebesar 6,75 , PB memperlihatkan rata-rata nilai $\mathrm{pH}$ yaitu 6,7, pada perlakuan $\mathrm{PC}$ yaitu 6,9 dan $\mathrm{PO}$ memperlihatkan nilai $\mathrm{pH}$ yaitu 6,3. Sedangkan pada hari ke-20 terjadi peningkatan $\mathrm{pH}$ pada perlakuan $\mathrm{PA}, \mathrm{PB}, \mathrm{PC}$, dan P0. PA dan PB memperlihatkan nilai $\mathrm{pH}$ yaitu 6,8 hingga hari ke-25 sedangkan pada P0 yaitu 6,5 . Dan pada hari ke-30 semua perlakuan mengalami peningkatan yaitu mendekati $\mathrm{pH}$ netral yaitu pada perlakuan PA 6,85, PB 6,8, PC 6,95 dan P0 yaitu 6,7. Perubahan pH kompos dapat dilihat pada Gambar 4.

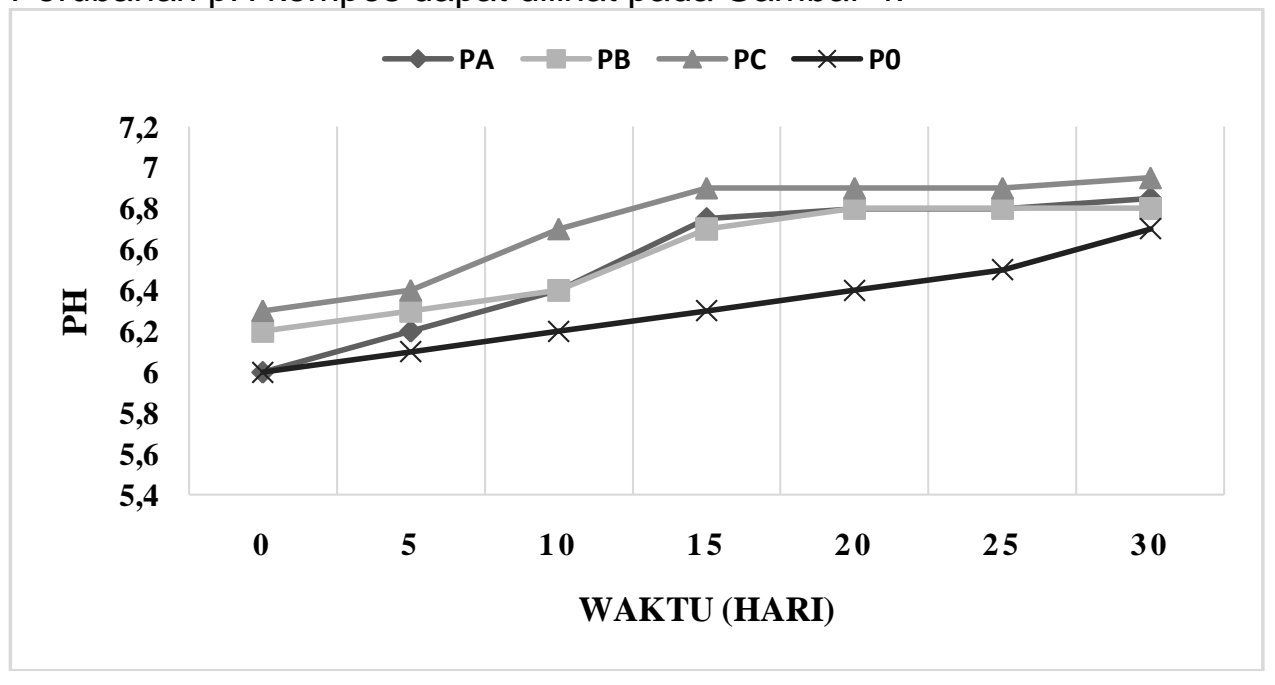

Gambar 4. Perubahan pH dekomposisi seresah daun Jati Tectona grandis L.f.,

Hasil pengamatan $\mathrm{pH}$ memperlihatkan pada awal pengomposan yaitu pada hari ke-0 pH mengalami kenaikan hingga akhir pengomposan. Hal ini disebabkan oleh mikroba menggunakan asam organik yang akan menyebabkan $\mathrm{pH}$ menjadi naik, selanjutnya asam organik digunakan mikroba jenis lain hingga derajat keasaman kembali netral (Maradhy, 2009). Rata-rata pH akhir dari proses dekomposisi pada tiap 
perlakuan mendekati $\mathrm{pH}$ netral yaitu 6,8-6,95. Menurut Hadisumarno (1992), $\mathrm{pH}$ ideal dekomposisi aerobik antara 6,0-8,0 karena pada derajat tersebut mikroba dapat tumbuh dan melakukan aktifitas dalam dekomposisi sampah organik.

\section{Laju Dekomposisi Kompos}

Laju dekomposisi selama 30 hari dapat dilihat pada Gambar 5. Nilai rata-rata laju dekomposisi tertinggi adalah perlakuan PC yaitu 0,65 dan terendah pada perlakuan P0 yaitu 0,50 . Hari ke-20 terjadi penurunan laju dekomposisi pada masingmasing perlakuan. Nilai rata-rata laju dekomposisi tertinggi adalah perlakuan PC yaitu 0,52 dan terendah pada perlakuan P0 yaitu 0,42 . Hari ke-30 semua perlakuan mengalami penurunan. Nilai rata-rata laju dekomposisi tertinggi adalah perlakuan PB yaitu 0,46 dan terendah pada perlakuan $\mathrm{P} 0$ yaitu 0,40 .

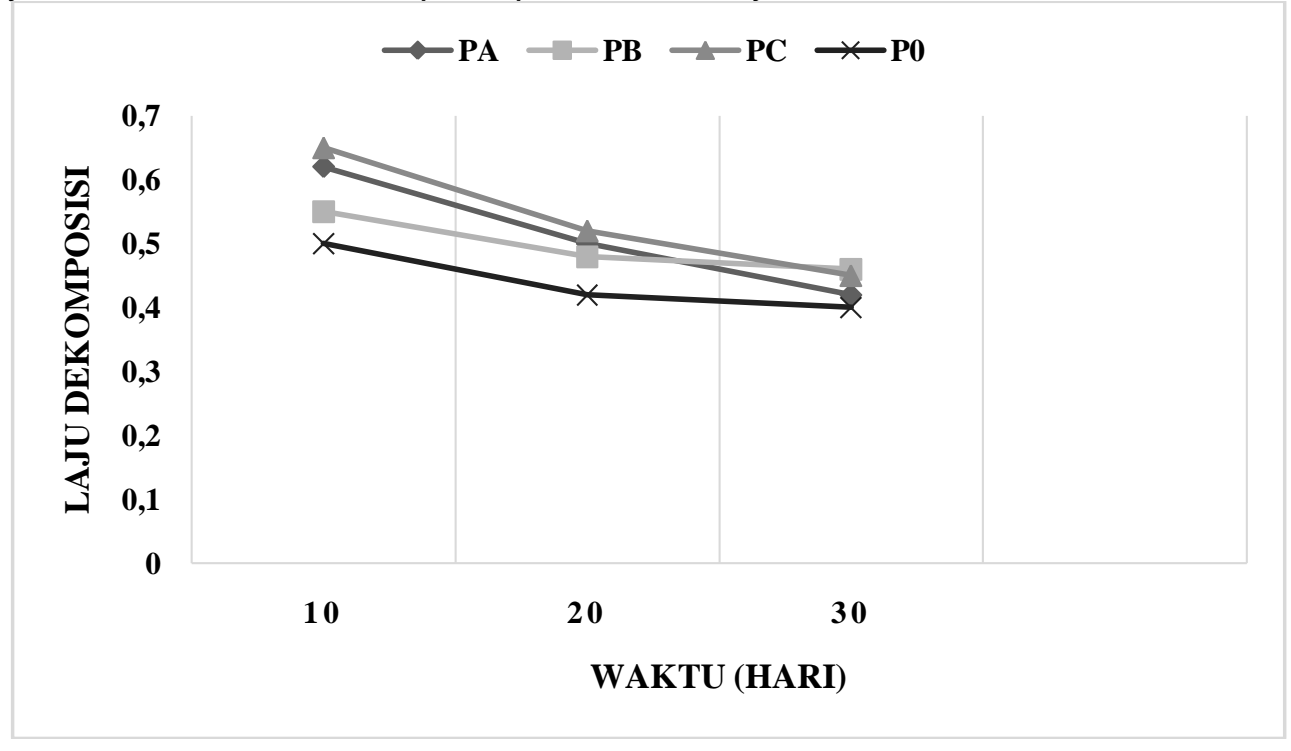

Gambar 5. Perubahan laju dekomposisi seresah daun Jati Tectona grandis L.f.,

Hasil penelitian menunjukkan bahwa telah terjadi penurunan berat dari berat awal daun pada semua perlakuan, sangat maksimal terjadi pada minggu pertama proses dekomposisi. Di antara semua perlakuan paling menunjukkan laju dekomposisi paling paling tinggi yaitu pada PA dan PC, dari minggu pertama sampai minggu ke tiga jika di bandingkan dengan perlakuan lainnya. Bedanya bioaktivator yang diberikan akan sangat menentukan kemampuan proses dekomposisi. Dari hasil penelitian dapat disimpulkan bahwa dengan adanya peningkatan laju dekomposisi dapat dilakukan dengan adanya penambahan bioaktivator.

Selama proses pengomposan, laju dekomposisi setiap perlakuan lama kelamaan mengalami penurunan sampai pada akhir pengomposan. Hal ini disebabkan karena bahan organik yang tersedia semakin lama semakin sedikit yang disebabkan oleh aktifitas mikroba yang menguraikan sampah organik. Menurut Notohadiprawiro (1998), laju dekomposisi bahan organik ditentukan oleh faktor bahan organiknya sendiri dan faktor luar lingkungan. Faktor lingkungan bertindak lewat pengaruhnya atas pertumbuhan dan metabolisme jasad renik pengurai. Faktor lingkungan yang terutama berpengaruh ialah suhu, kelembaban, $\mathrm{pH}$, dan potensial redoks. Faktor dakhil adalah susunan kimia bahan organik. Bahan organik yang lebih banyak mengandung selulosa, hemiselulosa, dan senyawa-senyawa larut air lebih mudah terurai. Menurut Maradhy (2009) Proses dekomposisi bahan organik secara alami akan berhenti bila faktor-faktor pembatasnya tidak tersedia atau telah dihabiskan dalam proses 
dekomposisi itu sendiri. Di dalam pengomposan akan terjadi perubahan yang dilakukan oleh mikroorganisme, yaitu berupa penguraian selulosa, hemiselulosa, lemak, serta bahan lainnya menjadi karbondioksida $\left(\mathrm{CO}_{2}\right)$ dan air. Dengan adanya perubahan-perubahan tersebut, maka bobot dan isi bahan dasar kompos akan menjadi berkurang antara 40-60\%, tergantung bahan dasar kompos dan proses pengomposannya (Yuwono, 2005), pengomposan secara aerobik akan mengurangi bahan komposan sebesar $50 \%$ dari bobot awalnya.

\section{Kadar Bahan Organik (Rasio $\mathrm{C} / \mathrm{N}$ )}

Hasil akhir dari kegiatan dekomposisi seresah daun Jati Tectona grandis L.f., adalah terjadi penguraian bahan-bahan organik menjadi karbon $(C)$ dan nitrogen yang nantinya untuk memperoleh rasio $\mathrm{C} / \mathrm{N}$. Organisme pengurai menggunakan karbon sebagai sumber energi dan nitrogen sebagai sumber protein. Rasio $\mathrm{C} / \mathrm{N}$ yang diinginkan dari kompos yang dihasilkan adalah menyamai rasio $\mathrm{C} / \mathrm{N}$ tanah yaitu 10-12 (Suwardi, 2004). Rasio C/N merupakan faktor penting pengomposan karena unsur hara terkait pada rantai karbon, sehingga rantai karbon panjang diputus agar nisbah diserap oleh tanaman (Permana, 2010). Hasil pengamatan rasio C/N dapat dilihat pada Tabel 1 dan Tabel 2.

Tabel 1. Kadar Bahan Organik Sebelum Dekomposisi

\begin{tabular}{|c|c|c|c|}
\hline \multirow{2}{*}{ Perlakuan } & \multicolumn{2}{|c|}{ Bahan Organik } & \multirow{2}{*}{ C/N Rasio } \\
\cline { 2 - 3 } & $\mathrm{C}(\%)$ & $\mathrm{N}(\%)$ & 17,8 \\
\hline PA & 3,20 & 0,18 & 17,9 \\
\hline PB & 2,87 & 0,16 & 36,5 \\
\hline PC & 2,55 & 0,07 & 15,9 \\
\hline P0 & 3,18 & 0,20 & \\
\hline
\end{tabular}

Tabel 2. Kadar Bahan Organik Setelah Dekomposisi

\begin{tabular}{|c|c|c|c|}
\hline \multirow{2}{*}{ Perlakuan } & \multicolumn{2}{|c|}{ Bahan Organik } & \multirow{2}{*}{ C/N Rasio } \\
\cline { 2 - 3 } & $\mathrm{C}(\%)$ & $\mathrm{N}(\%)$ & 14,5 \\
\hline PA & 3,17 & 0,22 & 12,9 \\
\hline PB & 2,59 & 0,20 & 10,8 \\
\hline PC & 2,36 & 0,22 & 8,73 \\
\hline P0 & 2,18 & 0,25 & \\
\hline
\end{tabular}

Pengamatan rasio $\mathrm{C} / \mathrm{N}$ dilakukan sebelum dan setelah proses dekomposisi. Hasil pengamatan menunjukkan bahwa rasio $\mathrm{C} / \mathrm{N}$ mengalami penurunan yakni pada perlakuan PA sebesar 14,5, diikuti perlakuan PB sebesar 12,9, diikuti perlakuan PC 10,8 serta yang paling rendah pada perlakuan $\mathrm{P} 0$ 8,73. Penurunan rasio $\mathrm{C} / \mathrm{N}$ terjadi selama masa pengomposan diakibatkan adanya penggunaan karbon sebagai sumber energi dan hilang dalam bentuk $\mathrm{CO}_{2}$ sedangkan nitrogen digunakan mikroba untuk sintesis protein dan pembentukan sel-sel tubuh sehingga kandungan karbon semakin lama semakin berkurang dan kandungan nitrogen yang tinggi maka rasio $\mathrm{C} / \mathrm{N}$ menjadi rendah.Menurut Isroi (2008), senyawa karbon dalam kompos akan menurun karena banyak yang digunakan untuk sumber energi bagi organisme dan selanjutnya hilang sebagai $\mathrm{CO}_{2}$. 
Hal ini sesuai dengan ketentuan SNI: 19-7030-2004 pada Tabel 3 tentang spesifikasi kompos yaitu rasio $\mathrm{C} / \mathrm{N}$ yang optimum adalah $10-20 \%$.

Tabel 3. Perbandingan Hasil Penelitian dengan Standar Nasional Indonesia (SNI 197020-2004) (Wahyono, 2010).

\begin{tabular}{|c|c|c|c|c|c|c|c|c|}
\hline \multirow[t]{2}{*}{ Parameter } & \multirow[b]{2}{*}{ PA } & \multicolumn{3}{|c|}{$\begin{array}{c}\text { Rata-rata hasil } \\
\text { penelitian hari ke-30 } \\
\text { perlakuan }\end{array}$} & \multicolumn{3}{|c|}{ SNI 2004} & \multirow[t]{2}{*}{$\begin{array}{c}\text { Sumber } \\
\text { lain* }\end{array}$} \\
\hline & & PB & $P C$ & P0 & Satuan & Min & Max & \\
\hline Suhu & 28,2 & 28,7 & 28,75 & 28 & ${ }^{0} \mathrm{C}$ & 26 & $\begin{array}{l}\text { Suhu } \\
\text { air } \\
\text { tanah } \\
(30)\end{array}$ & $27-30$ \\
\hline Kadar Air & 32,1 & 30,6 & 36 & 19,8 & $\%$ & & & $50-60$ \\
\hline $\mathrm{Ph}$ & 6,85 & 6,8 & 6,95 & 6,7 & Unit & 6,8 & 7,49 & $6,5-8,0$ \\
\hline $\begin{array}{l}\text { Laju } \\
\text { Dekomposi } \\
\text { si }\end{array}$ & 0,42 & 0,46 & 0,45 & 0,40 & $\begin{array}{l}\text { Gram } \\
\text { /hari }\end{array}$ & & & \\
\hline C- organik & 3,20 & 2,87 & 2,55 & 3,18 & $\%$ & 9,80 & 32 & \\
\hline $\mathrm{N}$ - total & 0,18 & 0,16 & 0,07 & 0,20 & $\%$ & 0,40 & & \\
\hline $\mathrm{C} / \mathrm{N}$ rasio & 14,5 & 12,9 & 10,8 & 8,73 & $\%$ & 10 & 20 & $20-25$ \\
\hline
\end{tabular}

Menurut Marady (2009) penguraian bahan-bahan organik yang terkandung dalam sampah organik daun adalah hasil kegiatan penguraian oleh mikroorganisme dan selanjutnya diperlukan oleh mikroorganisme itu sendiri sebagai sumber energi. Adanya perbedaan hasil penguraian bahan organik dapat disebabkan oleh perbedaan bioaktivator yang diberikan dan kandungan mikroorganisme yang ada dalam aktivator. Hadisumarno (1992) menyatakan bahwa lebih sepertiga unsur $\mathrm{C}$ berubah dan menyatu dalam kompos, sedangkan dua pertiga bagian lainnya menjadi $\mathrm{CO}_{2}$ dan tidak bermamfaat bagi lingkungan. Jika mikroba sudah mati maka unsur $\mathrm{N}$ akan tinggal dalam kompos.

Menurut Isroi (2008) rasio $\mathrm{C} / \mathrm{N}$ akan mempengaruhi ketersediaan unsur hara, rasio $\mathrm{C} / \mathrm{N}$ berbanding terbalik dengan ketersediaan unsur hara, artinya bila rasio $\mathrm{C} / \mathrm{N}$ tinggi maka kandungan unsur hara sedikit tersedia untuk tanaman, sedangkan jika rasio $\mathrm{C} / \mathrm{N}$ rendah maka ketersediaan unsur hara tinggi dan tanaman dapat memenuhi kebutuhan hidupnya. Selama proses pengomposan rasio $\mathrm{C} / \mathrm{N}$ akan terus menurun. Kompos yang matang memiliki rasio $\mathrm{C} / \mathrm{N}$ kurang dari 20. Sementara menurut Standar Nasional Indonesia (SNI 19-7020-2004) kompos matang memiliki rasio C/N sebesar 10-20, seperti yang terlihat pada Tabel 3 ..

\section{Kesimpulan}

1. Pemberian 3 jenis bioaktivator yaitu kotoran sapi, kotoran ayam, dan EM4 memberikan pengaruh terhadap laju dekomposisi seresah daun Jati Tectona grandis L.f., terutama pada bioaktivator EM4 dengan nilai laju dekomposisi yaitu 0,65 , nilai ini lebih tinggi dibanding dengan pemberian bioaktivator lainnya. 
2. Selama proses dekomposisi terjadi perubahan fisik berupa perubahan warna daun dimana terdapat perbedaan perubahan warna daun yang diberi bioaktivator yaitu dari kuning kecoklatan menjadi coklat kehitaman dan daun yang tidak diberi bioaktivator atau kontrol yaitu dari kuning kecoklatan menjadi coklat. Perlakuan daun Jati Tectona grandis L.f., dengan campuran bioaktivator EM4 menunjukkan nilai tertinggi untuk suhu yaitu $31,5^{\circ} \mathrm{C}$, kadar air $60,52 \%$, dan $\mathrm{pH}$ yaitu 6,95 . Perlakuan daun Jati Tectona grandis L.f., tanpa bioaktivator menunjukan nilai terendah untuk suhu $28^{\circ} \mathrm{C}$, kadar air $48,16 \%$, dan $\mathrm{pH}$ yaitu 6,7 , serta pada pengukuran rasio $\mathrm{C} / \mathrm{N}$ memenuhi SNI pada perlakuan $\mathrm{PA}, \mathrm{PB}$, dan $\mathrm{PC}$ yaitu 10-20.

\section{Daftar Pustaka}

Allo, M. P. R., 2014. Pengaruh Jenis Bioaktivator Pada Laju Dekomposisi Sampah Daun Ki Hujan Samanea saman dari Wilayah Kampus Unhas. Jurusan Biologi FMIPA Universitas Hasanuddin. Makassar.

Baon, J. B., 1996. Tata Cara Pengomposan Belotong. Warta Pusat Penelitian Kopi dan Kakao 12 ( 2).

Dalzell, H.W.et al., 1987. Soil Management: Compost Production and Use in Tropical and Subtropical Environtments. Soil Bulletin 56; Food and Agriculture Organization of the United Nations.

Gaur, A.C., 1986. A Manual of Rural Composting. FAO/UNDP Regional Project Divition of Microbiology. Indian Agricultural Research Institute. New Delhi.

Hadisumarno, D., 1992. Buku Panduan Teknik Pembuatan Kompos dan Sampah Teori dan Aplikasi. Center for Policy and Implemantation Studies (CPIS). Jakarta.

Hanum, M. A., Kuswytasari, N. D., 2014. Laju Dekomposisi Serasah Daun Trembesi (Samanea saman) dengan Penambahan Inokulum Kapang. Jurnal Sains dan Seni Pomits, 3 (1).

Isroi. 2008. Kompos. Badai Penelitian Bioteknologi Perkebunan Indonesia. Bogor.

Isroi dan Yuliarti. 2009. Kompos Cara Mudah, Murah Dan Cepat Menghasilkan Kompos. Lily Publisher. Yogyakarta.

Maradhy, E., 2009. Aplikasi Campuran Kotoran Ternak Dan Sedimen Mangrove Sebagai Aktivator Pada Proses Dekomposisi Limbah Domestik. Tesis. Pasca Sarjana Universitas Hasanuddin. Makassar.

Notohadiprawiro, T., 1998. Tanah Dan Lingkungan. Direktorat Jenderal Pendidikan Tinggi. DEPDIKBUD. Jakarta.

Rochaeni,et al.,2003. Pengaruh Komposisi Bahan Baku dan Lama Pengomposan Terhadap Mutu Kompos. Warta Pusat Penelitian Kopi dan Kakao, 11 (1)

Sucipto, C. D., 2012. Teknologi Pengolahan Daur Ulang Sampah. Gosyen Publishing. Yogyakarta.

Sukanto. 2013. Pembuatan Agen Bioaktivator untuk pengolahan kotoran ternak Menjadi Pupuk Organik Majemuk Secara Fermentasi. http://bio. unsoed. ac.id/sites/default/files/Pembuatan\%20Agen\%20Bioaktivator\%20untuk\%20Pen golahan\%20Kotoran\%20Ternak\%20menjadi\%20Pupuk\%20Organik\%20majem uk\%20secara\%20Fermentasi-.pdf. Diakses pada tanggal 8 Februari 2016.

Suwardi, 2004. Teknologi Pengomposan Bahan Organik Sebagai Pilar Pertanian Organik. Departemen IImu Tanah dan Sumber Daya Lahan. Fakultas Pertanian Institut Pertanian Bogor. Bogor. Hal. 28.

Syahwan, F. L., 2010. Kualitas Produk Kompos dan Karakteristik Proses Pengomposan Sampah Kota Tanpa Pemilahan Awal. Jakarta. Jurnal Teknik Lingkungan, 1 (1): 79-85. 
Wahyono, S., 2003. Mengolah Sampah Menjadi Kompos. Edisi Pertama. Jakarta.

Widawati, S., 2005. Daya Pacu Aktivator Fungi Asal Kebun Biologi Wamena Terhadap Kematangan Hara Kompos, Serta Jumlah Mikroba Pelarut Fosfat Dan Penambat Nitrogen. Biodiversitas, .6 (4): 240-243.

Yulipriyanto, H., 2009. Laju Dekomposisi Pengomposan Sampah Daun dalam Sistem Tertutup. Jurusan Pendidikan Biologi FMIPA Universitas Negeri Yogyakarta. Yogyakarta.

Yuniwati, M., Optimasi Kondisi Proses Pembuatan Kompos dari Sampah Organik dengan Cara Fermentasi Menggunakan EM4. Diakses pada tanggal 10 Februari, 2016.

Yuwono, D., 2005. Kompos. Seri Agritekno. Jakarta. Jurnal Sains dan Teknologi, 7 (2): 58-61. 